\title{
ANALISIS PENERAPAN BUNGA PINJAMAN DENGAN METODE SLIDING RATE DAN FLAT RATE PADA KOPERASI KREDIT GENTIARAS PRINGSEWU
}

\author{
Felix Alfa Yudhistira ${ }^{1}$, Yohanes Suharsana ${ }^{2}$ \\ 1,2Sekolah Tinggi IImu Ekonomi Gentiaras Bandar Lampung \\ Email : y.suharsana@gmail.com
}

\section{ABSTRACT}

Kopdit Gentiaras Pringsewu doing giving flowers with Sliding rate method. Sliding rate method is a method of charging interest each month is calculated from the remainder of the loan so the interest paid members monthly decreases with decreasing principal.

In order to compete with other cooperatives in other cooperative Pringsewu in Pringsewu, Kopdit GENTIARAS set loan interest rate by a sliding method. However, these methods do not necessarily provide benefits to its members.

This research uses case study research with descriptive approach. Analysis of the data used is quantitative analysis. Results from this study is the difference in interest grouping. Calculation method of sliding rate is $1.75 \% \mathrm{x}$ the remainder of the principal while the flat rate is $1.75 \% \mathrm{x}$ the loan early.

The results of this study provide the conclusion that the method of sliding rate is more beneficial to the members who make loans in Kopdit Gentiaras Pringsewu. Because by using this method the loan interest will always decreases with decreasing remainder of the loan.

\section{Keywords: Sliding Loan Interest Rate and Flat Rate}

\section{PENDAHULUAN}

\subsection{Latar Belakang}

Salah satu Koperasi Kredit atau Koperasi Simpan Pinjam yang berkembang di Lampung khususnya daerah Pringsewu adalah Koperasi Simpan Pinjam (KSP) Kopdit UBEKA ALBERTUS Gentiaras Pringsewu yang berdiri pada tanggal 31 maret 1988 berbadan hukum No. 116/BH/KDK.7.1/V/1999, merupakan anggota Gerakan Koperasi Kredit Indonesia (GKKI) dan Puskopdit Caraka Utama Lampung.

Koperasi Kredit Gentiaras telah memiliki anggota 10.000 dan anggota yang masih aktif sekitar 7.000. Dengan anggota aktif dapat memberikan kontribusi kepada Kopdit Gentiaras dengan pinjaman, Koperasi Simpan Pinjam (KSP) Kopdit Gentiaras Pringsewu mengambil keuntungan salah satunya dari bunga pinjaman.

Bunga pinjaman merupakan harga yang harus dibayar kepada anggota bagi yang memiliki simpanan dan harus dibayar oleh anggota kepada lembaga keuangan yang memperoleh pinjaman. Bukan koperasi yang diuntungkan dengan adanya bunga pinjaman melainkan anggota juga akan diuntungkan melalui bunga pinjaman yang tidak memberatkan anggota.

Bunga pinjaman atau pembebanan suku bunga ada 3 macam yaitu metode Sliding Rate, metode Flat Rate dan floating rate. Metode Sliding Rate merupakan pembebanan bunga setiap bulan dihitung dari sisa pinjaman sehingga jumlah bunga yang dibayar anggota setiap bulan menurun seiring dengan menurunnya pokok pinjaman.

Bunga yang diberikan pada Kopdit Gentiaras Pringsewu adalah 1,75\%, perhitungan bunga pada Kopdit Gentiaras Pringsewu hanya dengan metode sliding rate $(1,75 \%$ menurun). Namun mengingat situasi dan kondisi, metode tersebut dapat sewaktuwaktu dapat mengalami perubahan, hal ini yang akan dianalisa oleh penulis yaitu menganalisi perbandingan bunga pinjaman di Kopdit Gentiaras Pringsewu. 


\subsection{Perumusan Masalah}

1. Bagaimana perhitungan dan penerapan bunga pinjaman dengan metode sliding rate di Kopdit Gentiaras Pringsewu?

2. Bagaimana perhitungan dan penerapan bunga pinjaman dengan metode flat rate di Kopdit Gentiaras Pringsewu?

\subsection{Tujuan Penelitian}

1 Memahami perhitungan dan penerapan metode bunga pinjaman yang lebih meguntungkan bagi anggota dan koperasi bila mengunakan metode sliding rate di Kopdit Gentiaras Pringsewu.

2 Memahami perhitungan dan penerapan metode bunga pinjaman yang lebih meguntungkan bagi anggota dan koperasi bila mengunakan metode flat rate di Kopdit Gentiaras Pringsewu.

\section{TINJAUAN PUSTAKA}

\subsection{Pengertian Koperasi}

Koperasi merupakan singkatan dari kata Co dan Operation. Koperasi adalah suatu kumpulan orang - orang untuk bekerja sama demi kesejahteraan bersama. Berdasarkan undang - undang nomor 12 tahun 1967, Koperasi Indonesia adalah organisasi ekonomi rakyat yang berwatak social dan beranggotakan orang-orang, badan-badan hukum koperasi yang merupakan tata susunan ekonomi sebagai usaha bersama berdasar atas asas kekeluargaan. Berikut ini adalah landasan koperasi Indonesia yang melandasi aktifitas koperasi di Indonesia: Landasan Idiil (Pancasila); Landasan Mental (Setia kawan dan kesadaran diri sendiri); Landasan Struktural dan gerak (UUD 1945 Pasal 33 Ayat 1).

Koperasi adalah juga gerakan yang terorganisasi yang didorong oleh cita - cita rakyat mencapai masyarakat yang maju, adil dan makmur seperti yang diamanatkan oleh UUD 1945 khususnya pasal 33 ayat (1) yang menyatakan bahwa

Definisi Koperasi Menurut Undang Undang No. 25 Tahun 1992 Undang - undang No. 25 tahun 1992, memberikan definisi "Koperasi adalah badan usaha yang beranggotakan orang-orang atau badan hukum koperasi yang melandaskan kegiatannya berdasarkan prinsip koperasi sekaligus sebagai gerakan ekonomi rakyat yang berdasar atas asas kekeluargaan". Berdasarkan batasan koperasi, koperasi Indonesia mengandung 5 unsur sebagai berikut :

1. Koperasi adalah badan usaha (Business Enterprise)

2. Koperasi adalah kumpulan orang-orang dan atau badan-badan hokum koperasi

3. Koperasi Indonesia adalah koperasi yang bekerja berdasarkan "prinsip - prinsip koperasi"

4. Koperasi Indonesia adalah "Gerakan Ekonomi Rakyat".

5. Koperasi Indonesia "berazaskan kekeluargaan".

\subsection{Tujuan dan Prinsip Koperasi}

Tujuan utama koperasi adalah mewujudkan masyarakat adil makmur material dan spiritual berdasarkan Pancasila dan Undang-Undang Dasar 1945. Dalam BAB II Pasal 3 Undang-Undang RI No. 25 Tahun 1992, menyatakan bahwa koperasi bertujuan untuk memajukan kesejahteraan anggota pada khususnya dan masyarakat pada umumnya serta ikut membangun tatanan perekonomian nasional dalam rangka mewujudkan masyarakat yang maju, adil dan makmur berlandaskan Pancasila dan Undang-Undang Dasar 1945. Menurut Bang Hatta, tujuan koperasi bukanlah mencari laba yang sebesarbesarnya, melainkan melayani kebutuhan bersama dan wadah partisipasi pelaku ekonomi skala kecil.

Menurut UU No.17 tahun 2012 Prinsipprinsip koperasi adalah garis-garis penuntun yang digunakan oleh koperasi untuk melaksanakan nilai-nilai tersebut dalam praktik.

a. Prinsip pertama, keanggotaan sukarela dan terbuka; Koperasi-koperasi adalah perkumpulan-perkumpulan sukarela, terbuka bagi semua orang yang mampu menggunakan jasa-jasa perkumpulan dan bersedia menerima tanggung jawab keanggotaan, tanpa diskriminasi jender, social, rasial, politik atau agama

b. Prinsip kedua, Pengendalian oleh anggota secara demokratis; Koperasi- koperasi 
adalah perkumpulan-perkumpulan demokratis yang dikendalikan oleh para anggota secara aktif berpartisipasi dalam penetapan kebijakan-kebijakan perkumpulan dan mengambil keputusankeputusan. Pria dan wanita mengabdi sebagai wakil-wakil yang dipilih, bertanggung jawab kepada para anggota.

c. Prinsip ketiga, Partisipasi Ekonomi Anggota; Anggota-anggota menyumbang secara adil dan mengendalikan secara demokrasi modal dari koperasi mereka. Sekurang-kurangnya koperasi. Anggotaanggota biasanya menerima kompensasi yang terbatas, bilamana ada, terhadap modal.

d. Prinsip keempat, Otonomi Dan Kebebasan; Koperasi-koperasi bersifat otonom, merupakan perkumpulanperkumpulan yang menolong diri sendiri dan dikendalikan oleh anggotaanggotanya.

e. Prinsip kelima, Pendidikan, Pelatihan, dan Informasi; Koperasi- koperasi menyelenggarakan pendidikan dan pelatihan bagi anggota- anggotanya, para wakil yang dipilih, manajer dan karyawan, sehingga mereka dapat memberikan sumbangan yang efektif bagi perkembangan koperasi-koperasi mereka.

f. Prinsip keenam, Kerjasama diantara Koperasi; Koperasi - koperasi akan dapat memberikan pelayanan paling efektif kepada para anggota dan memperkuat gerakan koperasi dengancara bekerja sama melalui struktur-struktur lokal, nasional, regional, dan internasional.

g. Prinsip ketujuh, Kepedulian Terhadap Komunitas; Koperasi-koperasi bekerja bagi pembangunan yang berkesinambungan dari komunikasikomunitas mereka melalui kebijakan kebijakan yang disetujui oleh anggotaanggotanya.

\subsection{Pengertian suku bunga}

Pengertian suku bunga menurut Boediono (2014) adalah harga dari penggunaan dana pijaman. Suku bunga adalah salah satu indicator dalam menentukan apakah seseorang akan berinvestasi atau menabung. Adapun fungsi suku bunga adalah:

1. Sebagai daya tarik bagi para penabung yang mempunyai dana lebih untuk diinvestasikan.

2. Suku bunga dapat digunakan sebagai alat monster dalam rangka mengendalikan penawaran dan permintaan uang yang beredar dalam suatu perekonomian.

3. Pemerintah dapat memanfaatkan suku bunga untuk mengontrol jumlah uang beredar. Ini berarti, pemerintah dapat mengatur sirkluasi uang dalam suatu perekonomian. Suku bunga itu sendiri ditentukan oleh dua kekuatan, yaitu :enawaran tabungan dan permintaan investasi modal (terutama dari seketor bisnis). Tabungan adalah selisih antara pendapatan dan konsumsi.

Bunga pada dasarnya berperan sebagai pendorong utama agar masyarakat bersedia menabung. Jumlah tabungan akan ditentukan oleh tinggi rendahnya tingkat bunga. Semakin tinggi suku bunga, akan semakin tinggi juga minat masyarakat untuk menabung, dan sebaliknya. Tinggi rendahnya penawaran dan investasi ditentukan oleh rendahnya suku bunga tabungan masyarakat.

Bunga dapat diartikan sebagai balas jasa yang diberikan oleh lembaga keuangan seperti bank dan koperasi kepada anggotanya yang membeli atau menjual produknya. Bunga juga dapat diartikan sebagai harga yang harus dibayar kepada nasabah bagi yang memiliki simpanan dan harus dibayar oleh nasabah kepada lembaga keuangan yang memperoleh pinjaman. Ada dua macam bunga yang harus diberikan kepada nasabah yaitu sebagai berikut

1. Bunga simpanan, bunga yang diberikan sebagai rangsangan atau balas jasa bagi nsabah yang menyimpan uangnya di lembaga keuangan seperti bank atau koperasi, bunga simpanan merupakan harga yang harus dibayar oleh lembaga keuangan kepada anggota, seperti jasa giro, bunga tabungan, dan bunga deposito. 
2. Bunga pinjaman, Merupakan bunga yang diberikan kepada para peminjam atau harga yang harus dibayar oleh anggota atau jasa pinjaman. Sebagai contoh bunga kredit.

Kedua macam bunga ini merupakan komponen utama faktor biaya dan pendapatan. Bunga simpanan adalah biaya dana yang harus dikeluarkan kepada nasabah, sedangkan bunga pinjaman merupakan pendapatan yang diterima dari anggota. Baik bunga simpanan maupun bunga pinjaman masing-masing mempengaruhi satu sama lainnya.

\subsection{Komponen-komponen dalam menentukan bunga kredit}

Untuk menentukan besar kecilnya suku bunga kredit yang akan diberikan kepada para debitur terdapat beberapa komponen yang mempengaruhi. Komponen-komponen dalam menentukan suku bunga kredit, Kasmir (2012) adalah sebagai berikut: a. Total biaya dana (cost of fund)

Merupakan total bunga yang dikeluarkan untuk memperoleh dana simpanan baik dalam bentuk simpanan giro, tabungan maupun deposito. Total biaya dana tergantung dari seberapa besar bunga yang ditetapkan untuk memperoleh dana yang diinginkan. Semakin besar bunga yang dibebankan terhadap bunga simpanan, semakin tinggi pula biaya dananya demikian pula sebaliknya.

Dalam melakukan setiap kegiatan membutuhkan berbagai sarana dan perasarana baik berupa manusia maupun alat. Penggunaan sarana dan prasarana ini memerlukan sejumlah biaya yang harus ditanggung sebagai bentuk kegiatan oprasi. biaya oprasi ini terdiri dari biaya gaji pegawai, biaya administrasi, biaya pemeliharaan, dan biaya-biaya lainnya.

Sedangkan Cadangan resiko kredit
macet merupakan cadangan terhadap macetnya kredit yang akan diberikan, hal ini disebabkan setiap kredit yang diberikan pasti mengandung sebuah resiko tidak terbayar. Resiko ini dapat timbul baik disengaja maupun tidak disengaja. Oleh karena itu, perlunya sikap bersiaga menghadapinya denga cara membebankan sejumlah presentase teertentu terhadap kredit yang disalurkan.

Setiap melakukan transaksi pasti selalu ingin memperoleh laba yang makasimal. Penentuan ini ditentukan oleh beberapa pertimbangan penting, mengingat penentuan besarnya laba sangat mempengaruhi besarnya bunga kredit. Hal ini melihat kondisi persaingan dan kondisi anggota. Demikian pula Pajak merupakan kewajiban yang dibebankan pemerintah kepada lembaga keuangan yang memberikan fasilitas kredit kepada nasabahnya.

\subsection{Hipotesis}

$\mathrm{H} 1$ : Penerapan bunga pinjaman dengan metode sliding rate memberikan keuntungan anggotanya di Kopdit Gentiaras Pringsewu.

H2 : Penerapan bunga pinjaman dengan metode flat rate memberikan keuntungan anggotanya di Kopdit Gentiaras Pringsewu.

\section{METODOLOGI PENELITIAN}

\subsection{Jenis Penelitian}

Penelitian merupakan suatu proses mencari sesuatu secara sistematik dalam waktu yang lama dengan menggunakan metode ilmiah serta aturan-aturan yang berlaku. Dalam menyusun skripsi ini, penulis menggunakan metode penelitian evaluasi. Penelitian evaluasi yaitu menganalisis melalui study kasus sehingga penulis dapat menganalisis untuk kemudian menarik suatu kesimpulan.

\subsection{Tempat dan Waktu Penelitian}

Tempat Penelitian : Kopdit Gentiaras Pringsewu, Jl. Kesehatan No.70 PringsewuLampung. Waktu Penelitian Febuari 2019 sampai dengan April 2019

\subsection{Sumber Data}

Data sekunder merupakan sumber data penelitian yang diperoleh peneliti secara tidak langsung melalui media perantara (diperoleh oleh pihak lain). Data sekunder umumnya berupa bukti, catatan atas laporan historis yang telah tersusun dalam arsip (data 
dokumenter) yang dipublikasikan dan yang tidak dipublikasikan.

\subsection{Populasi dan Sampel}

Populasi dalam penelitian ini adalah jangka waktu angsuran pada Kopdit Gentiaras Pringsewu anatara lain: angsuran 6 bulan, 12 bulan, 24 bulan, 36 bulan, 48 bulan, 60 bulan, 72 bulan dan 84 bulan. Dalam penelitian ini penulis mengambil sampel dari laporan pinjaman.

\subsection{Teknik Analisis Data}

1. Analisis Deskriptif; adalah analisis yang digunakan untuk menganalisis data dengan cara mendeskripsikan atau mengambarkan data yang yang telah terkumpul sebagaimana adanya. Teknik analisis ini bisa digunakan untuk penelitian penelitian yang besifat explorasi.

2. Analisis Kuantitatif; merupakan analisis yang menggunakan angka yang dikonfrensikan ke dalam rumus. (Sugiyono: 2013). Dalam penelitian ini penulis melakukan analisis dengan menggunakan analisis dengan menggunakan metode sliding rate, metode Flat rate adalah sebagai berikut:

a. Metode Sliding rate; pembebanan bunga setiap bulan dihitung dari sisa pinjaman sehinga jumlah bunga yang anggota terima seiring dengan turunnya pokok pinjaman.(kasmir: 2012) Akan tetapi pembayaran pokok pinjaman setiap bulan selalu sama. Cicilan anggota (pokok pinjaman ditambah bunga, otomatis dari bulan kebulan semakin menurun.

b. Metode Flat Rate; yaitu dengan metode cara perhitungan bunga rumus flat rate Adalah pembebanan bunga terhadap nilai pokok pinjaman akan tetap dari suatu periode ke periode lainnya walaupun pokok pinjaman menurun sebagai akibat adanya pembayaran cicilan pokok pinjaman (Kasmir 2012)

\section{ANALISIS DAN PEMBAHASAN \\ 4.1 Analisis Data \\ 1. Penentuan metode pinjaman}

a. Metode sliding rate

Sliding rate adalah metode pembebanan bunga yang menghitung bunga dari sisa pinjamannya sehingga jumlah bunga yang dibayar anggota setiap bulannya semakin menurun, namun untuk pokok pinjamannya tetap sama di setiap bulannya. Penetapan metode ini sangat menguntungkan dan meringankan anggota, beban bunga yang harus dibayar nasabah akan terus mengecil atau berkurang (Kasmir 2012)

b. Metode flat rate

Flat rate adalah (Kasmir: 2012) pembebanan bunga setiap bulan tetap dari jumlah pinjamannya, demikian pula pokok pinjaman setiap bulan juga dibayar sama sehingga cicilan setiap bulan sama sampai kredit tersebut lunas. perhitungan bunga yang dihitung dengan metode flat rat

Dari data tabel 1, Perhitungan bunga angsuran dengan total pinjaman pada bulan Febuari sebesar Rp 3.816.800.000 dari 95 peminjam dengan total bunga dihitung dengan metode sliding rate selama bulan Febuari adalah Rp 1.480.291.620 dan dengan metode flat rate sebesar $\mathrm{Rp} 2.976 .768 .750$ dengan selisih bunga sebasar Rp 1.496.477.130.

. Dari data tabel 2, Perhitungan bunga angsuran dengan total pinjaman pada bulan Maret sebesar Rp 4.221.100.000 dari 89 peminjam dengan total bunga dihitung dengan metode sliding rate selama bulan maret adalah Rp 1.509.028.875 dan dengan metode flat rate sebesar Rp 2.947.468.500 dengan selisih bunga sebasar Rp 1.438.439.625. 
Tabel 1.

Perhitungan pinjaman dengan metode sliding rate dan flat rate bulan Febuari 2019

\begin{tabular}{ccrrr}
\hline $\begin{array}{c}\text { Jumlah } \\
\text { peminjam }\end{array}$ & $\begin{array}{c}\text { Jangka waktu } \\
\text { angsuran }\end{array}$ & Total pinjaman & $\begin{array}{c}\text { Bunga sliding } \\
\text { rate (Rp) }\end{array}$ & Bunga flat rate (Rp) \\
\hline 12 & 6 & 130.500 .000 & 107.919 .000 & 107.919 .000 \\
\hline 31 & 12 & 301.900 .000 & 33.986 .875 & 57.036 .250 \\
\hline 22 & 24 & 556.200 .000 & 126.042 .750 & 236.860 .000 \\
\hline 14 & 36 & 1.151 .200 .000 & 366.547 .250 & 734.706 .000 \\
\hline 4 & 48 & 302.000 .000 & 212.482 .500 & 253.680 .000 \\
\hline 8 & 60 & 773.000 .000 & 412.591 .750 & 812.087 .500 \\
\hline 3 & 72 & 526.000 .000 & 264.122 .500 & 662.760 .000 \\
\hline 1 & 84 & 76.000 .000 & 56.525 .000 & 111.720 .000 \\
\hline & & 3.816 .800 .000 & 1.480 .291 .620 & 2.976 .768 .750 \\
\hline
\end{tabular}

Sumber: Laporan pinjaman bulan Febuari

Tabel 2.

Perhitungan pinjaman dengan metode sliding dan rate flat rate Bulan Maret 2019

\begin{tabular}{ccrrr}
\hline Peminjam & $\begin{array}{c}\text { Jangka waktu } \\
\text { angsuran }\end{array}$ & \multicolumn{1}{c}{ Total pinjaman } & $\begin{array}{c}\text { Bunga sliding } \\
\text { rate (Rp) }\end{array}$ & Bunga flat rate (Rp) \\
\hline 11 & 6 & 23.700 .000 & 1.451 .625 & 2.488 .500 \\
\hline 22 & 12 & 188.000 .000 & 21.382 .750 & 39.468 .000 \\
\hline 27 & 24 & 946.000 .000 & 206.937 .500 & 396.828 .000 \\
\hline 18 & 36 & 1.279 .400 .000 & 343.952 .000 & 669.294 .000 \\
\hline 4 & 48 & 316.000 .000 & 13.5485 .000 & 265.440 .000 \\
\hline 6 & 60 & 1.313 .000 .000 & 700.813 .750 & 1.378 .650 .000 \\
\hline 1 & 72 & 155.000 .000 & 99.006 .250 & 195.300 .000 \\
\hline & 84 & & & \\
\hline
\end{tabular}

Sumber: Laporan pinjaman bulan Maret

Tabel 3.

Perhitungan pinjaman dengan metode sliding dan rate flat rate Bulan April 2019

\begin{tabular}{ccrrr}
\hline Peminjam & $\begin{array}{c}\text { Jangka waktu } \\
\text { angsuran }\end{array}$ & Total pinjaman & \multicolumn{1}{c}{$\begin{array}{c}\text { Bunga sliding } \\
\text { rate (Rp) }\end{array}$} & \multicolumn{1}{c}{$\begin{array}{c}\text { Bunga flat rate } \\
\text { (Rp) }\end{array}$} \\
\hline 10 & 6 & 99.050 .000 & 6.101 .813 & 10.400 .250 \\
\hline 18 & 12 & 650.500 .000 & 73.992 .875 & 136.593 .000 \\
\hline 10 & 24 & 197.000 .000 & 43.093 .250 & 82.740 .000 \\
\hline 15 & 36 & 1.037 .500 .000 & 320.385 .625 & 623.367 .000 \\
\hline 5 & 48 & 555.000 .000 & 237.956 .250 & 466.200 .000 \\
\hline 4 & 60 & 898.000 .000 & 479.307 .500 & 942.900 .000 \\
\hline 1 & 72 & 65.000 .000 & 415.187 .50 & 81.900 .000 \\
\hline 1 & 84 & 150.000 .000 & 111.562 .500 & 220.500 .000 \\
\hline & & 3.652 .050 .000 & 1.313 .918 .563 & 2.564 .600 .250 \\
\hline
\end{tabular}

Sumber: Laporan pinjaman bulan April

Dari data diatas, Perhitungan bunga angsuran dengan total pinjaman pada bulan April sebesar $\operatorname{Rp} 3.652 .050 .000$ dari 64 peminjam dengan total bunga dihitung dengan metode sliding rate selama bulan April adalah $\mathrm{Rp}$ 1.313.918.563 dan dengan metode flat rate sebesar Rp 2.564.600.250 dengan selisih bunga sebasar Rp1.250.681.688. 


\subsection{Hasil Penelitian}

Klasifikasi pinjaman mengunakan metode sliding rate dan flat rate dengan bunga $1,75 \%$ perbulan dengan jangka waktu Febuari - april 2019

Tabel 4.

Perhitungan metode pinjaman pada bulan Febuari - April 2019

\begin{tabular}{ccc}
\hline \multirow{2}{*}{ Bulan } & \multicolumn{2}{c}{ Metode Pinjaman } \\
\cline { 2 - 3 } & $\begin{array}{c}\text { Sliding Rate } \\
(\mathrm{Rp})\end{array}$ & $\begin{array}{c}\text { Flat Rate } \\
(\mathrm{Rp})\end{array}$ \\
\hline Febuari & 1.480 .291 .620 & 2.976 .768 .750 \\
\hline Maret & 1.509 .028 .875 & 2.947 .468 .500 \\
\hline April & 1.313 .918 .563 & 2.564 .600 .250 \\
\hline Jumlah & 4.303 .239 .058 & 8.488 .837 .500 \\
\hline
\end{tabular}

Sumber : Laporan perhitungan bunga bulan Febuari - April

Dari data di atas, Perhitungan jumlah bunga metode sliding rate selama tiga bulan yaitu Febuari, Maret dan April adalah Rp 4.303.239.058. Lebih kecil bila dibandingkan

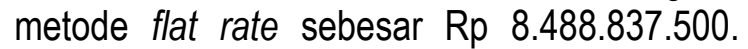
Jadi selisih antara metode sliding rate dan flat rate pada bulan Febuari - April di peroleh hasil sebesar Rp 4.185.598.442.

Berdasarkan rangkuman hasil pengujian diatas, maka pembahasan hasil pengujian untuk masing-masing hipotesis adalah sebagai berikut: $\mathrm{Ho}$ dalam penelitian ini diterima dan $\mathrm{Ha}$ dalam penelitian ini ditolak. Hal ini terjadi karena metode sliding rete lebih menguntungkan anggota koperasi di bandingkan dengan metode flat rate.

\section{SIMPULAN DAN SARAN}

\subsection{Simpulan}

1. Perhitungan bunga pinjaman dengan metode sliding rate lebih memberikan bunga yang lebih rendah pada bulan Febuari-April dengan nilai $\mathrm{Rp} R p$ 4.303.239.058.

2. Perhitungan bunga pinjaman dengan metode flat rate lebih memberikan bunga yang lebih rendah pada bulan Febuari April dengan nilai Rp 8.488.837.500.
3. Dengan perhitungan kedua metode tersebut metode sliding rate memberikan bunga yang lebih rendah dibandingakan flat rate ini akan memberikan keuntungan kepada anggota dengan bunga yang rendah anggota akan semakin tertarik untuk melakukan pengkreditan.

\subsection{Saran}

Kopdit Gentiaras Pringsewu dalam menghitung bunga pinjaman sebaiknya tetap menggunakan metode sliding rate dibandingkan dengan menggunakan metode , karena dengan menggunakan metode sliding rate akan lebih meringankan anggota dalam pembayaran bunga, ini akan memberikan dampak positif karena dengan ini anggota akan semakin bertambah sehingga Kopdit Gentiaras Pringsewu akan semakin berkembang dan menjadi lebih besar.

\section{DAFTAR PUSTAKA}

Abdul, Hanif. 2012. Pengaruh Modal Sendiri, Modal Pinjaman dan Volume Usaha Terhadap Sisa Hasil Usaha ( Studi Kasus Pada Koperasi Di Sukoharjo Tahun 2012. Surakarta: Universitas Muhamadiyah Surakarta.

Boediono. 2014. Ekonomi Internasional Pengantar IImu Ekonomi No.3.Penerbit : BPFE UGM.

Catur. 2015. Evaluasi sistem pemberian kredit study kasus di Credit Union Dharma Bakti Yogyakarta.

Ikatan Akuntansi Indonesia (2012), Standar Akuntanasi Keuangan. Jakarta: Salemba Empat

Kasnir. 2010. Manajemen perbankkan. Jakarta: Rajawali.

Kasmir. 2012. Analisis Laporan Keuangan. Jakarta: PT Raja Grafindo Persada

Kasmir. 2012. Bank Dan Lembaga Keuangan Lainnya. Jakarta: PT Raja Grafindo Persada

Kasmir. 2013. Analisis Laporan Keuangan. Jakarta: Rajawali

Kasmir. 2014. Bank Dan Lembaga Keuangan Lainnya. Edisi Revisi 2014. Jakarta: PT Raja Grafindo Persada 
Kasmir. 2015. Analisis Laporan Keuangan. Jakarta: PT Raja Grafindo Persada

Kopdit Gentiaras. 2015. Standar Operasional Manajemen: Ineern. (SOM)

Mulyono, Djoko. 2012. Buku Pintar Strategi Bisnis Koperasi Simpan Pinjam. Yogyakarta: CV Andi Ofsel

Sekaran, dan Roger Bougie. (2010). Edisi 5, Research Method For Business: A skill Building Approach. John Wiley @ Sons, New York

Seno, Gregorius. 2015. Evaluasi Sistem Pemberian Kredit Studi Kasus di Credit Union Dharma Bakti Yogyakarta. Yogyakarta: Universitas Sanata Dharma Yogyakarta.

STIE Gentiaras. 2019. Panduan Penulisan Sekrisi. Bandar Lampung.

Sugiyono. 2010. Metode Penelitian Kuantitatif, Kualitatif dan R\&D. Bandung: ALFABETA.

Sugiyono. 2013. Metode Penelitian Kuantitatif, Kualitatif dan R\&D. Bandung; ALFABETA.

Wijayanti, Beti. 2014. Analisis Penerapan Bunga Pinjaman Terhadap SHU.
Lampung: STIE Gentiaras Bandar Lampung.

Perundang Undangan : Undang Undang Republik Indoesia Nomor 12 Tahun 1967, Tentang Pokok - Pokok Pengkoprasian

Undang Undang Republik Indoesia Nomor 25 Tahun 1992. Tentang Perkoprasian.

Undang Undang Republik Indoesia Nomor 17 Tahun 2012. Tentang Perinsip Perinsip Koperasi

Undang Undang Republik Indoesia Nomor 25 Tahun 1992 Pasal 45 Ayat 1 Tentang Sisa Hasil Usaha,

www.google.blogspot.com.2015. Sejarah Perkembangan Koperasi di Indonesia

Nawiyah, Warizatul."Makalah Sejarah Koperasi di Dunia dan Indonesia". 11 Maret 2016. http://nwarizareza.blogspot.co.id/2013/06/makalahsejarah-koperasi-di-dunia-dan-html.

Masngudi. "Penelitian tentang sejarah akoperasi di Indonesia" 14 maret 2016. http://www.docsengine.com/pdf/1/sejarah-koperasi-didunia.html. 